\title{
Studi Eksperimen Karakteristik Kinerja Kincir Air sebagai Pembangkit Listrik Skala Mikrohidro
}

\author{
Baktiyar Mei Hermawan, Gatot Suwoto, Bono, Suwarti, Yusuf Dewantoro Herlambang*, \\ Mulyono, Azka Fikral Adiba, Jimmy Hartanto, Rivan Ma'rivan Elhas, Rizky Amelia R
}

\author{
Jurusan Teknik Mesin, Politeknik Negeri Semarang \\ Jl. Prof. H. Soedarto, S.H., Tembalang, Semarang, 50275 \\ "Email: masyusufdh@polines.ac.id
}

Diterima: 19-11-2021; Direvisi: 13-12-2021; Dipublikasi: 30-12-2021

\begin{abstract}
Abstrak
Masalah yang sering dijumpai di masyarakat dalam pemanfaatan sumber energi air pada saluran miring adalah masih sedikitnya jumlah ketersediaan kincir air yang bersekala mikro, karena untuk mendesain dan membuat kincir air ini perlu suatu kemampuan dan keahlian khusus. Pemanfaatan dan pengunaan kincir air pada saluran miring masih belum begitu optimal penggunaan dan pemakaiannya di Indonesia, hal tersebut dikarenakan masih minimnya informasi tentang pemanfaatan dan pengaplikasian kincir air pada saluran miring dalam pemanfaatannya di lapangan. Penelitian ini memiliki suatu tujuan untuk mengetahui putaran kincir, daya listrik dan efisiensi sistem pada pembangkit listrik mikrohidro. Untuk mengetahui karakteristik kincir air pada saluran miring sebagai pembangkit listrik skala mikrohidro. Metode penelitian diawali dengan perancangan/ desain kincir air, kemudian dilanjutkan tahap pembuatan, tahap assembling dan installing, pengujian alat dan analisis, pengujian yang dilakukan meliputi uji karakteristik kincir air. Parameter penelitian yang diukur meliputi putaran generator, arus yang mengalir pada rangkaian, tegangan yang mengalir pada rangkaian, beban lampu yang diberikan, debit air yang mengenai sudu. Hasil Penelitian kincir air putaran kincir tertinggi pada ketinggian poros kincir $21 \mathrm{~cm}$ diatas bibir saluran adalah 40,3 rpm dengan beban lampu 20 Watt, sedangkan putaran kincir terendah pada ketinggian poros $29 \mathrm{~cm}$ diatas bibir saluran adalah 35,9 rpm dengan beban lampu 40 Watt. Daya listrik tertinggi pada ketinggian poros kincir $21 \mathrm{~cm}$ diatas bibir saluran adalah 4,68 Watt dengan beban lampu 20 Watt. Efisiensi sistem tertinggi pada ketinggian poros kincir $21 \mathrm{~cm}$ diatas bibir saluran adalah $0,284 \%$ dengan beban lampu 20 Watt.
\end{abstract}

Kata kunci: PLTMH; Kincir air, saluran miring

\begin{abstract}
The problem that is often found in the community in the use of water energy sources in oblique channels is still the least amount of availability of micro-scale waterwheels, because to design and make this waterwheel needs a special ability and expertise. Utilization and use of waterwheels in oblique channels is still not so optimal for use and use in Indonesia, this is because there is still a lack of information about the utilization and application of waterwheels on oblique channel in their utilization in the field. This research aims to find out the ferris wheel rotation, electrical power and system efficiency in microhydro power plants.. To find out the characteristics of watermills on oblique channels as microhydro-scale power plants Research methods begin with the design / design of watermills, then continued the stage of manufacture, assembling and installing stages, tool testing and analysis, testing conducted includes watermill characteristics tests. The measured research parameters include the rotation of the generator, the current flowing on the circuit, the voltage flowing on the circuit, the load of the given lamp, the discharge of water that hits the spoon. The result of the highest ferris wheel rotation at the height of the ferris wheel shaft $21 \mathrm{~cm}$ above the lip of the channel is 40.3 rpm with a lamp load of 20 Watts, while the lowest ferris wheel rotation at the shaft height of $29 \mathrm{~cm}$ above the lip of the channel is $35.9 \mathrm{rpm}$ with a lamp load of 40 Watts. The highest electrical power at the height of the ferris wheel shaft $21 \mathrm{~cm}$ above the lip of the channel is 4.68 Watts with a light load of 20 Watts. The highest system efficiency at the height of the ferris wheel shaft $21 \mathrm{~cm}$ above the lip of the channel is $0.284 \%$ with a lamp load of 20 Watts
\end{abstract}

Kata kunci: PLTMH; waterwheel, oblique channel

\section{Pendahuluan}

Kebutuhan penggunaan dan pemakaian sumber energi listrik merupakan suatu kebutuhan pokok bagi masyarakat Indonesia pada umumnya. Pemanfaatan Bahan Bakar Minyak (BBM) sebagai bahan baku untuk Pembangkit Listrik 
secara terus menerus akan mengakibatkan ketersediaan sumber energi fosil akan terus menerus menurun. Berbagai energi alternatif yang saat ini sudah tersedia diantaranya adalah solar cell yang memanfaatkan energi surya dan energi panas bumi. Pemanfaatan energi alternatif yang bersumber dari potensi tenaga air untuk saat ini masih belum optimal untuk penggunaannya, sehingga bila potensi tenaga air ini dimanfaatkan dengan baik maka secara otomatis akan memberikan dampak yang signifikan dalam menunjang kemandirian energi. Energi terbarukan berperan sebagai diversifikasi energi [1]. Potensi sumber energi tenaga air Menurut Kementrian ESDM adalah sebanyak 15.600 MW [2], sedangkan untuk Pembangkit Listrik Tenaga Air potensi di Provinsi Jawa Tengah yang bisa untuk dikembangkan adalah sebesar 386,42 MW [3]. Pengembangan potensi sumber energi air ini apabila dimanfaatkan dengan baik akan memberikan manfaat bagi masyarakat sekitar. Pada dasarnya air sangat sering kita jumpai di sekitar kita [4]. Pembangkit listrik tenaga air memanfaatkan energi potensial dan energi kinetik menjadi daya angular turbin air [5].

Pemanfaatan potensi sumber energi air yang menggunakan penggerak kincir dari tenaga air di daerah yang memiliki geografis perbukitan dan memiliki potensi sumber air yang melimpah untuk saat ini masih minim, apabila potensi sumber air yang dimiliki dimanfaatkan sebaik- baiknya sebagai pembangkit listrik secara otomatis akan mengurangi ketergantungan masyarakat terhadap listrik yang bersumber dari Pembangkit Listrik Negara (PLN). Listrik merupakan kebutuhan pokok yang sangat penting [6]. Energi alternatif yang bisa digunakan untuk pembangkit tenaga air yang memiliki skala kecil/ mikro biasa dikenal mikrohidro. Untuk pada massa sekarang sumber energi listrik yang dominan digunakan masyarakat adalah bersumber dari pembangkit yang menggunakan bahan bakar fosil. Untuk mengurangi ketergantungan pada masyarakat terhadap pemanfaatan bahan bakar fosil untuk pembangkit, salah satunya dengan memanfaatkan sumber energi air pada saluran miring dengan menggunakan kincir air skala mikrohidro. Desain kincir relatif sederhana dan memiliki torsi tinggi [7] . Pemanfaatan energi air untuk penggerak kincir air akan menunjang kemandirian energi di suatu desa yang memiliki potensi sumber energi air yang cukup melimpah . Penelitian sebelumnya yang dilakukan S, Gatot [8] yang melakukan penelitian kinerja turbin air hasil modifikasi pompa sentrifugal menunjukkan hasil optimum didapat pada putaran turbin $1315 \mathrm{rpm}$. S, Gatot,dkk [9] hasil penelitian pengaruh sudut sudu pengarah aliran jet menunjukkan hasil optimum didapat pada sudu pengarah $16^{\circ}$. Sahid,dkk [10] melakukan penelitian pengaruh nosel berpenampang segi empat terhadap unjuk kerja menunjukkan efisiensi maksimum pada nosel berpenampang segi empat adalah sebesar 79,3\%. Wibawa, U,dkk [11] melakukan penelitian kincir air overshot menunjukkan daya sebesar $3,214 \mathrm{~kW}$ pada putaran $17,41 \mathrm{rpm}$. Penelitian sebelumnya yang dilakukan Ristianto, P,dkk [12] melakukan penelitian menggunakan dua generator serta turbin tunggal menghasilkan daya sebesar 6 kVA. Penelitian yang dilakukan Rahman, A, dkk [13] dengan debit aliran $1.8 \mathrm{~m} / \mathrm{s}$ didaptkan daya sebesar 14.51 watt. Penelitian sebelumnya yang dilakukan Suryanta, dkk [14] menunjukkan bahwa dengan menggunakan kincir air sudu bersirip dapat menghasilkan daya 1.5 kali lebih besar.

Dalam penelitian karakteristik kinerja kincir air sebagai pembangkit tenaga mikrohidro ini ditambahkan arm kincir yang berfungsi sebagai lintasan untuk menaikkan serta menurunkan kincir, serta terdapat fly bearing yang berfungsi tempat berputarnya kincir. Desa Surokonto Wetan, Kec. Pegeruyung Kab. Kendal adalah salah satu desa yang memiliki sumber energi air yang cukup melimpah untuk bisa digunakan dan juga dimanfaatkan oleh masyarakat sekitar sebagai suatu pembangkit listrik mikrohidro dalam menunjang kemandirian energi di Desa Surokonto.

Tujuan Penelitian ini adalah untuk mengetahui putaran kincir, daya listrik dan efisiensi sistem. Untuk mengetahui karakteristik kinerja kincir air pada saluran miring sebagai pembangkit listrik skala mikrohidro. Manfaat Penelitian ini adalah menambah pengetahuan mengenai pemanfaatan potensi air sebagai PLTMH dan mempelajari pemakaian dan penggunaan kincir air sebagai PLTMH. 


\section{Material dan Metodologi}

\subsection{Material}

Material yang digunakan dalam penelitian ini adalah sebagai berikut:

1. Bahan yang digunakan dalam pembuatan poros menggunakan baja poros pejal ST 60 dengan diameter 50 $\mathrm{mm}$, dengan panjang $6000 \mathrm{~mm}$.

2. Bahan yang digunakan dalam pembuatan kerangka kincir menggunakan besi hollow persegi $20 x 20$ $\mathrm{mm}$, dan beton eser $10 \mathrm{~mm}$ sebagai penyangga samping sudu.

3. Bahan yang digunakan pembuatan sudu kincir menggunakan plat besi $1.2 \mathrm{~mm} \mathrm{120 \times 240} \mathrm{mm}$.

4. Bahan yang digunakan dalam pembuatan arm kincir menggunakan besi pejal kotak $10 \times 10 \mathrm{~mm} 1100$ mm dengan penambahan plat di sisi samping kanan kiri setebal $1.2 \mathrm{~mm}$

\subsection{Metodologi}

Tahapan dalam proses penelitian yang dilakukan adalah seperti pada gambar 1 dibawah ini:

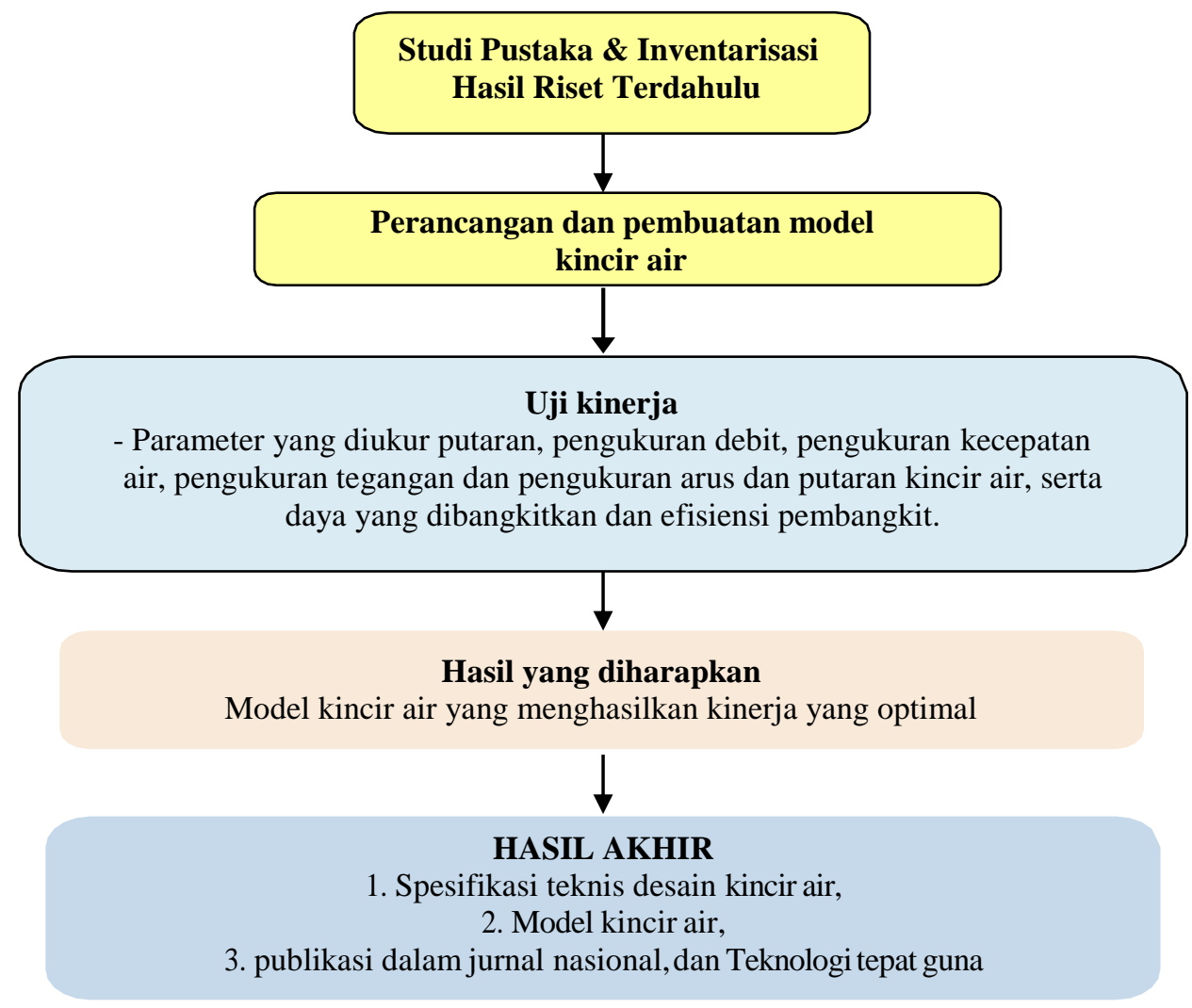

Gambar 1. Proses alur tahapan dalam penelitian

Dalam proses mendesain sebuah kincir air harus berdasarkan beberapa kriteria seperti kincir air diharuskan memiliki konstruksi yang kokoh dan juga kuat, memiliki ukuran yang sama pada tiap sudunya. Bila ditinjau dari kriteria tersebut maka dalam penelitian ini menggunakan jenis besi hollow persegi, kemudian beton esser yang digunakan sebagai kerangka kincir serta sebuah plat besi untuk sudu kincir air.

Diameter kincir air yang digunakan dalam penelitian ini adalah sebesar $1800 \mathrm{~mm}$ dimana terdiri 16 buah sudu dengan lebar $540 \mathrm{~mm}$. Gambar 2. dibawah ini adalah desain kincir air yang digunakan dalam penelitian ini. 


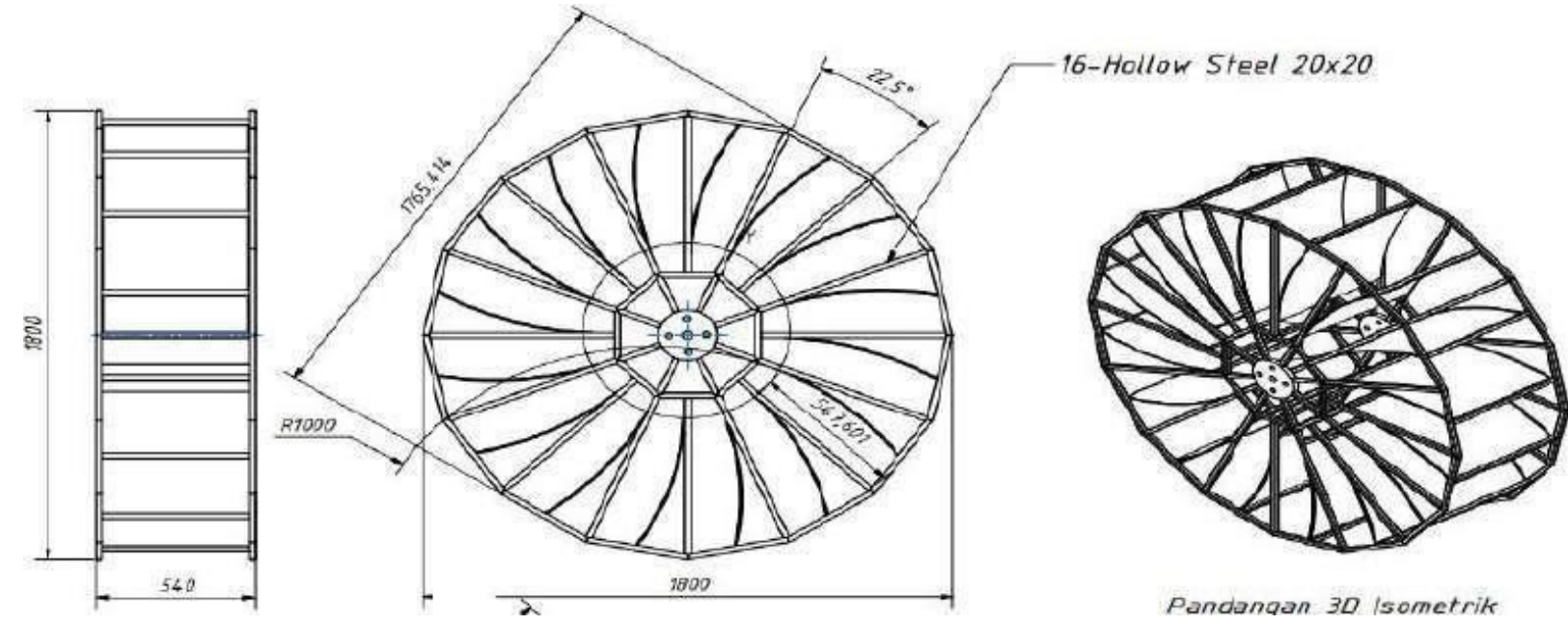

Gambar 2. Desain Kincir Air yang digunakan

Desain kerangka utama yang digunakan sebagai penopang kincir air yang akan digunakan pada saluran miring terbuat dari bahan besi dengan ukuran 60 x 5x $5 \mathrm{~mm}$. Desain kerangka utama untuk menopang kincir air seperti pada Gambar 3. dibawah ini.

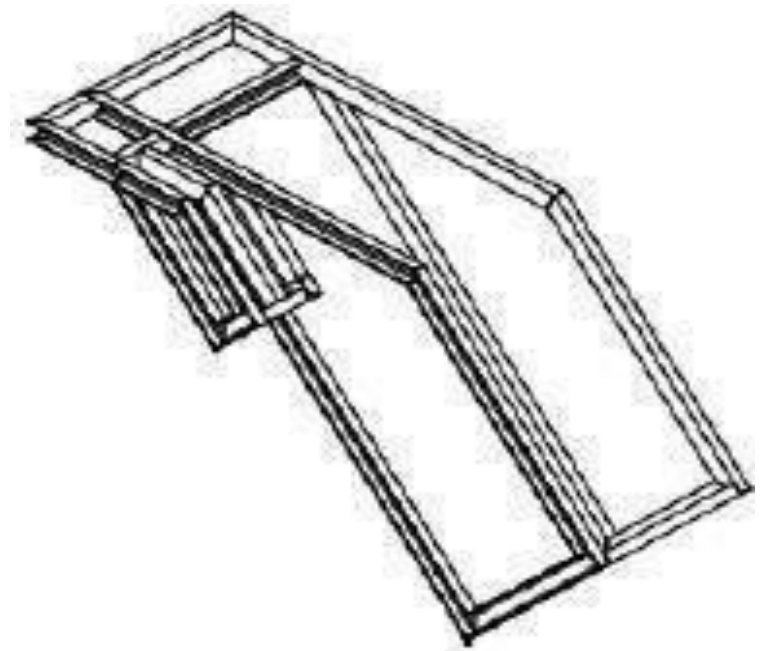

Gambar 3. Kerangka Utama Sebagai Penopang Kincir Air Pada Saluran Miring

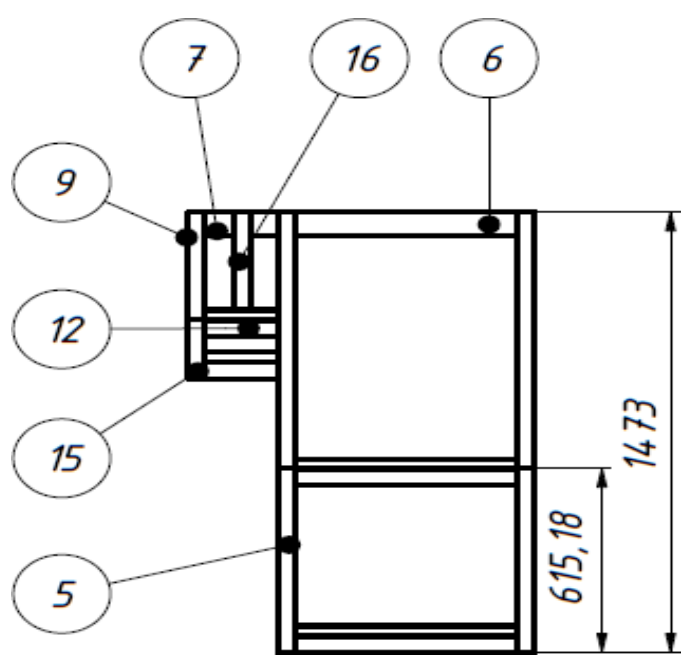


Baktiyar Mei Hermawan dkk /Jurnal Rekayasa Mesin

p-ISSN: 1411-6863, e-ISSN: 2540-7678

Vol.16|No.3|475-485|Desember|2021

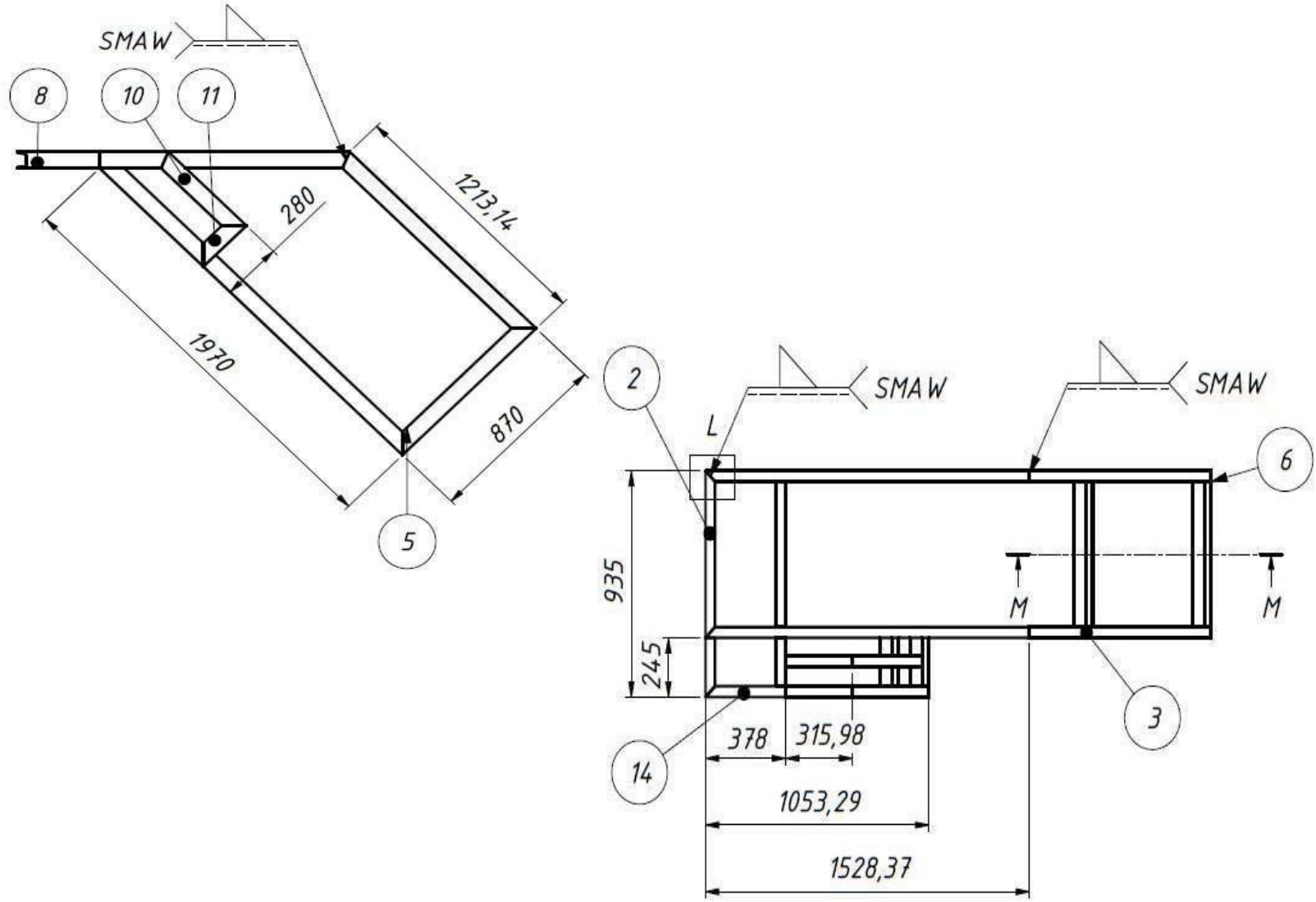

Gambar 4. Dimensi kerangka utama sebagai penopang kincir pada saluran miring

Arm kincir yang berfungsi sebagai lintasan untuk menaikkan dan menurunkan kincir. Pada arm kincir terdapat ulir yang berfungsi untuk menaikkan dan menurunkan serta terdapat fly bearing untuk tempat berputarnya kincir. Arm kincir ditunjukkan Gambar 5 dibawah ini:

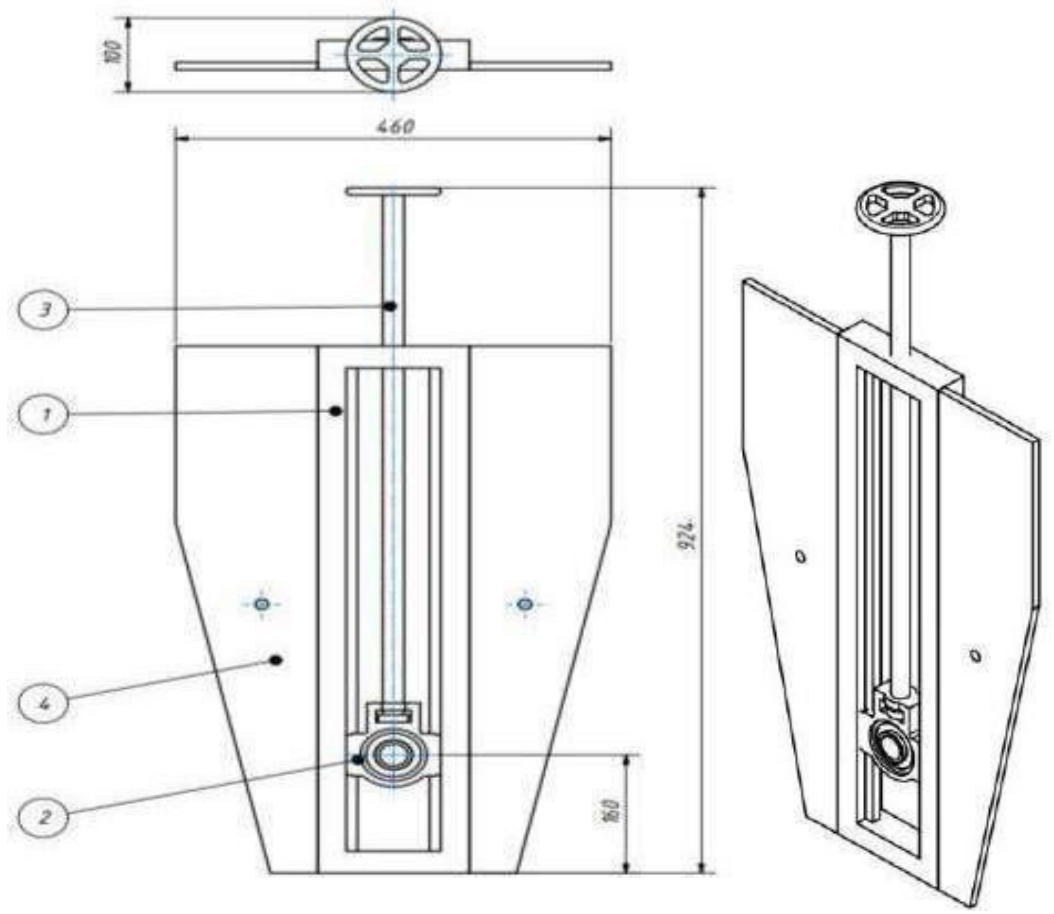

Gambar 5. Arm kincir 
Baktiyar Mei Hermawan dkk /Jurnal Rekayasa Mesin p-ISSN: 1411-6863, e-ISSN: 2540-7678 Vol.16|No.3|475-485|Desember|2021

Langkah- langkah dalam perakitan kincir air pada saluran miring adalah sebagai berikut langkah pertama menyiapkan semua peralatan dan juga bahan yang akan diperlukan dalam proses pemasangan kincir air pada saluran miring, langkah kedua mempersiapkan kerangka utama sebagai penopang kincir air pada saluran miring, langkah ketiga melakukan pemasangan kincir air pada saluran miring dengan memakai dynabolt, langkah keempat dengan melakukan pemasangan mur dan juga baut dengan menggunakan bantuan kunci pas, langkah kelima melakukan pemasangan pulley pada posisi yang telah ditentukan sebelumnya, langkah terakhir adalah melakukan pemasangan generator pada tempat yang telah disediakan. Rangkaian kincir air yang akan digunakan sebagai pembangkit listrik skala mikrohidro yang digunakan dalam penelitian ini adalah seperti pada Gambar 6 dibawah ini:

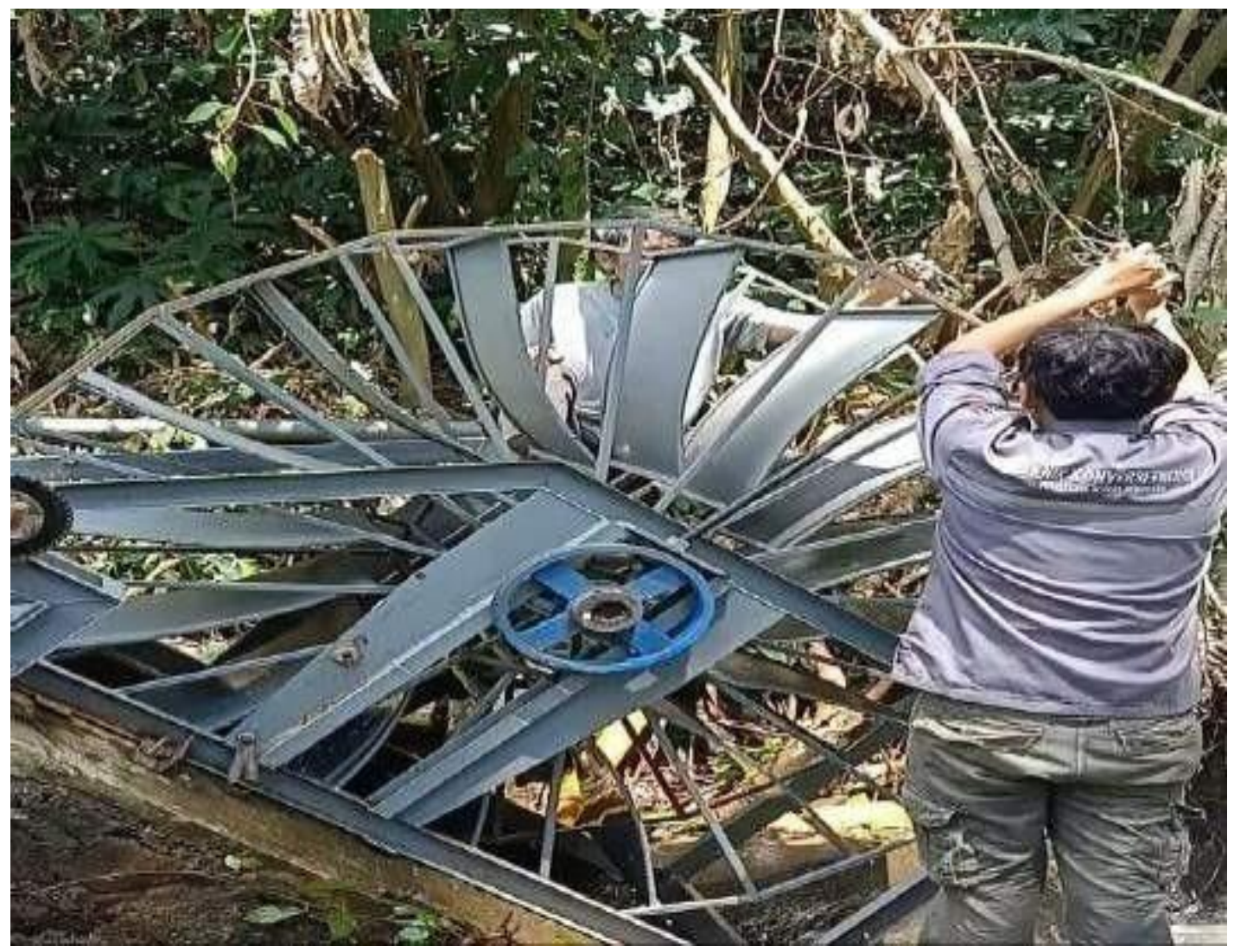

Gambar 6. Rangkaian Kincir Air Sebagai PLTMH Sumber: Dokumentasi pribadi

Dalam pengambilan data kinerja kincir air parameter yang diukur adalah putaran generator, arus yang mengalir pada rangkaian, tegangan yang mengalir pada rangkaian, beban lampu yang diberikan, debit air yang mengenai sudu. Setelah mendapatakan parameter maka didapatkan hasil kinerja kincir air. Langkah pengujian dalam penelitian ini adalah pertama kali kita harus menyiapkan peralatan yang akan dipakai dalam proses pengukuran yang meliputi alat tachometer, sebuah amperemeter, voltmeter, kedua mengukur head air dan kecepatan air, ketiga membuat rangkaian amperemeter, voltmeter, dengan kabel spade dan crocodille. Dari output generator dihubungkan dengan generator charge controller sebagai penyearah kemudian dari output penyearah dipasang amperemeter secara seri, voltmeter dan beban lampu secara pararel, keempat memasang sabuk pada pulley dan kemudian melakukan pengujian pada beban 0 watt, kemudian mengukur kecepatan putaran dengan menggunakan tachometer, selanjutnya melakukan pembacaan arus yang mengalir, membaca tegangan pada luaran generator, mengulangi langkah tersebut sampai 7-10 kali. 
Baktiyar Mei Hermawan dkk /Jurnal Rekayasa Mesin p-ISSN: 1411-6863, e-ISSN: 2540-7678 Vol.16|No.3|475-485|Desember|2021

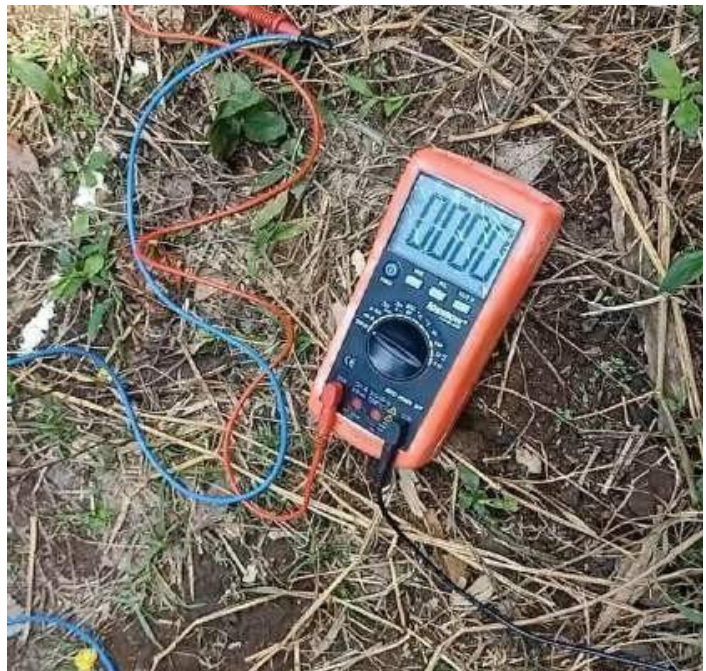

Gambar 7. Amperemeter

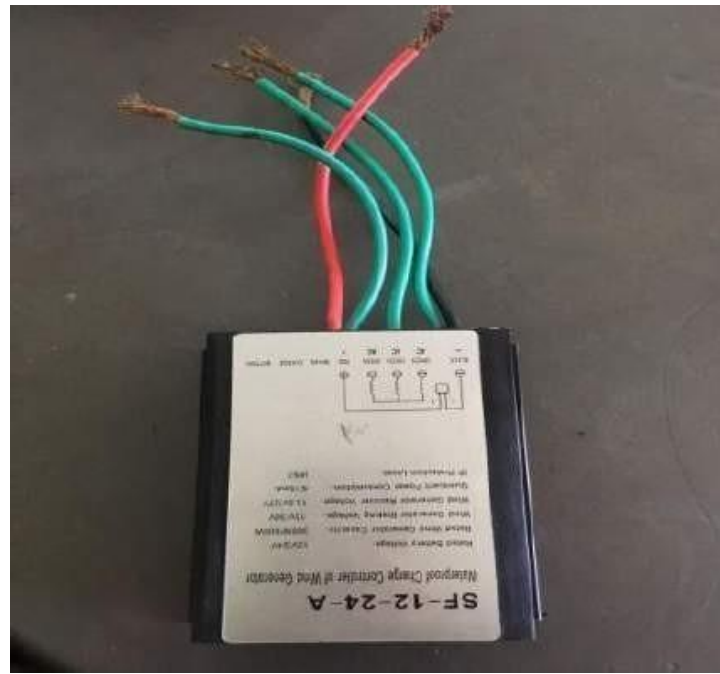

Gambar 8. Charge Controller

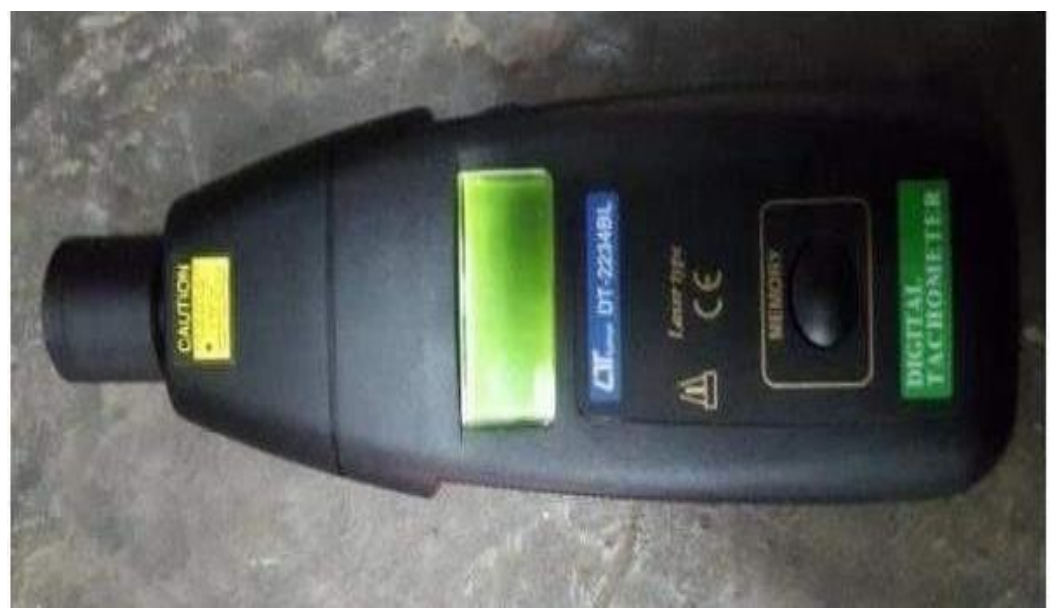

Gambar 9. Tachometer

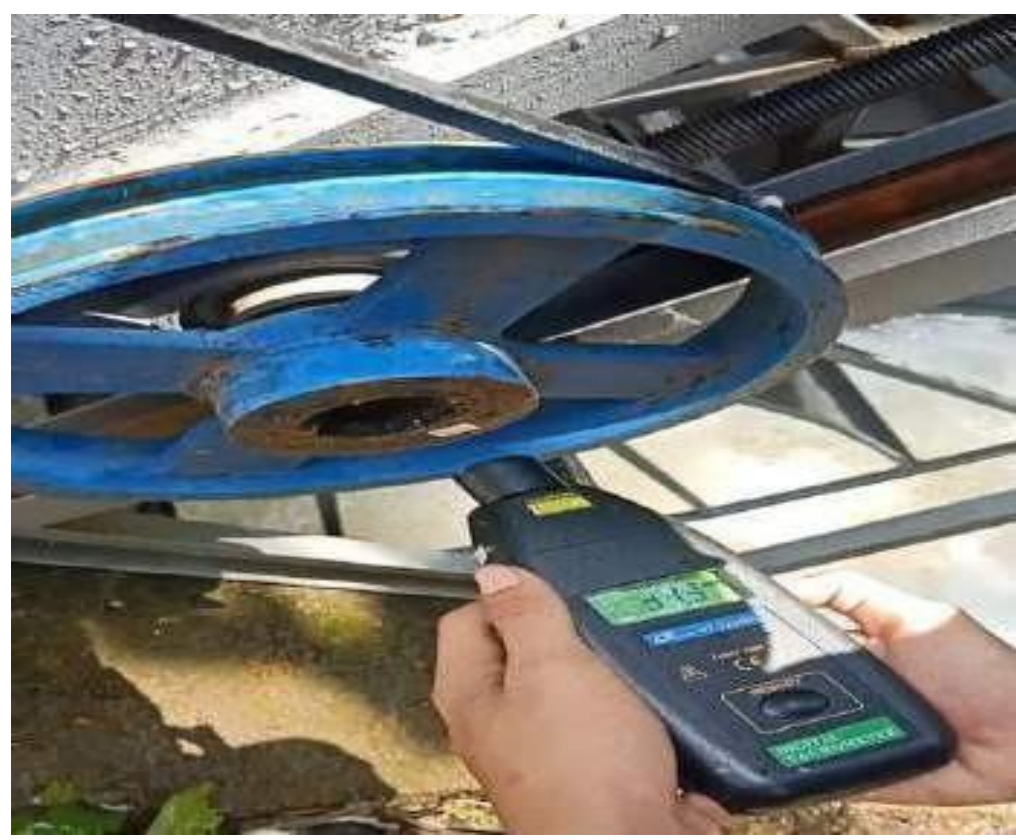

Gambar 10. Proses Pengukuran Kecepatan Putaran pada Poros Kincir 


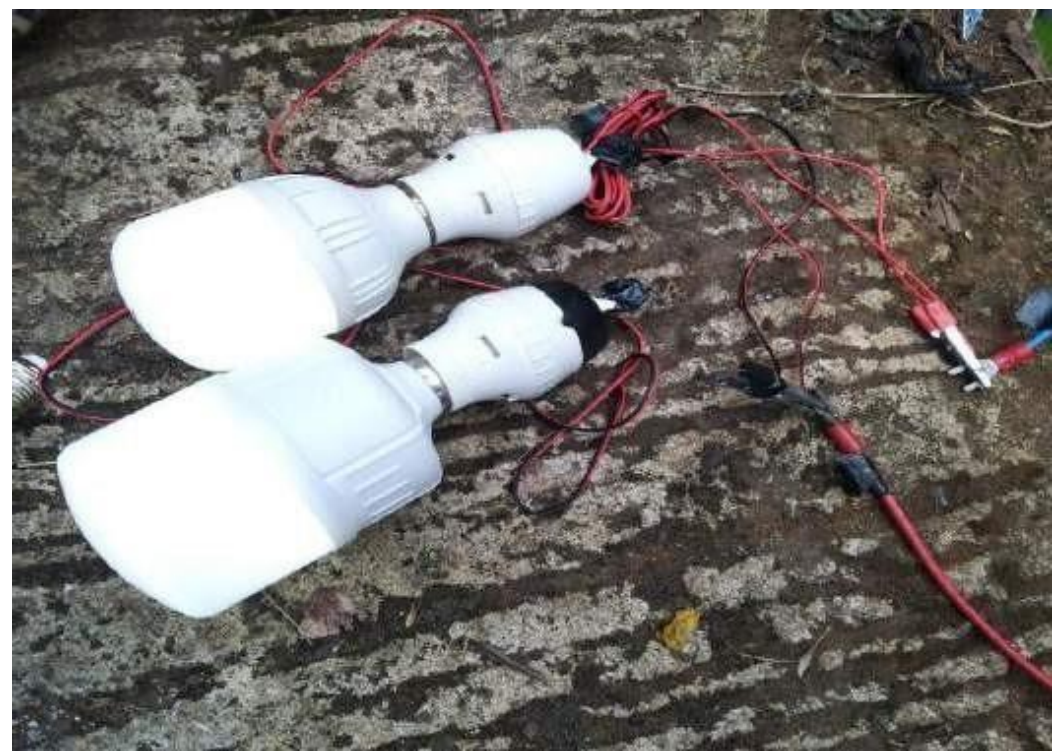

Gambar 11. Variasi Beban Pengujian Kincir

\section{Hasil dan Pembahasan}

Parameter pengukuran meliputi putaran generator $(\mathrm{n})$, arus yang mengalir pada rangkaian $(\mathrm{A})$, tegangan yang mengalir pada rangkaian $(\mathrm{V})$, beban lampu yang diberikan (Watt), debit air yang mengenai sudu $\left(\mathrm{m}^{3} / \mathrm{s}\right)$, serta kecepatan aliran air (m/s). Karakteristik variasi beban lampu terhadap putaran kincir dapat dilihat dalam pada Gambar 12 .

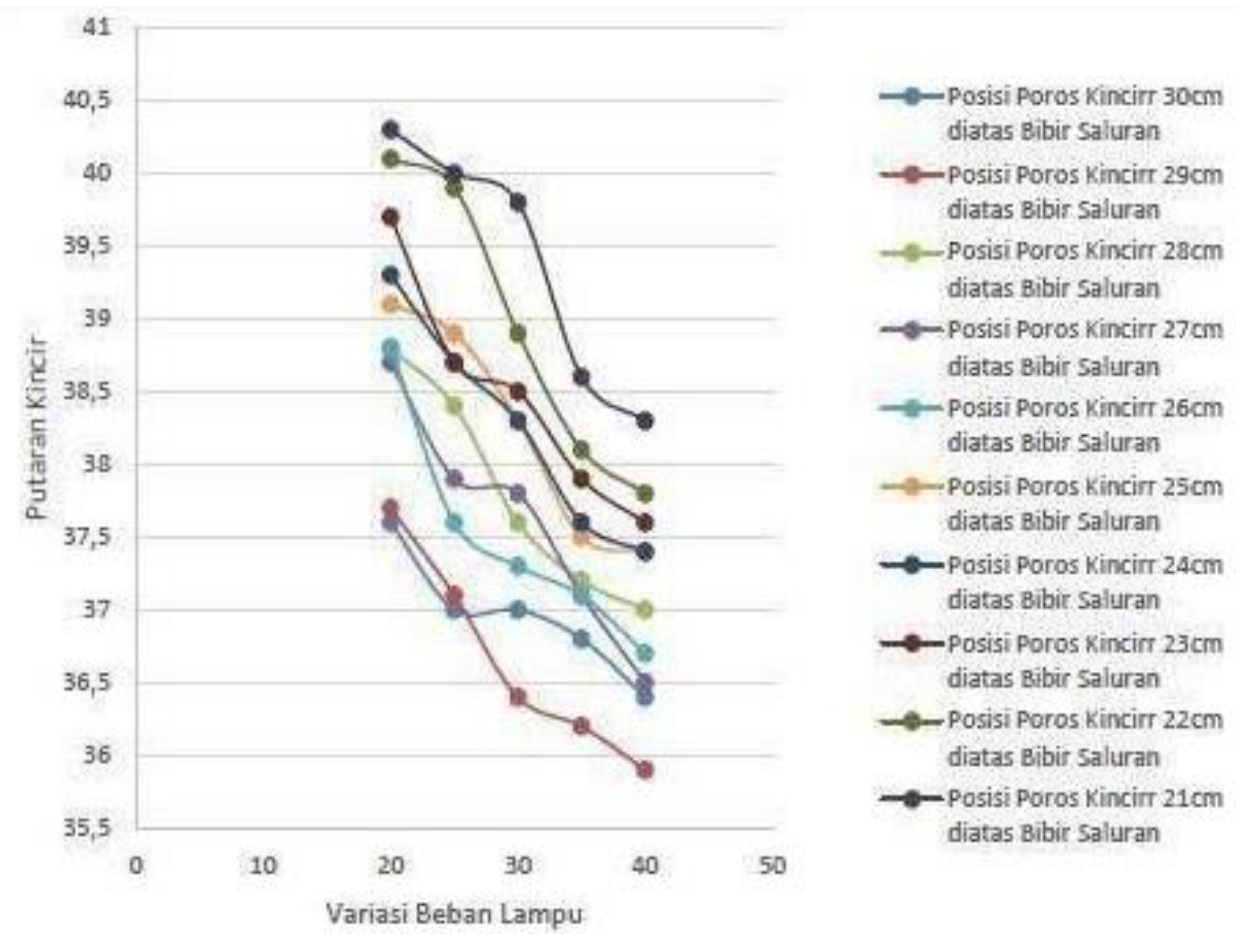

Gambar 12 . Karakteristik Variasi Pembebanan Pada Lampu terhadap Putaran Kincir

Pengujian yang telah dilakukan menunjukkan bahwa semakin meningkatnya beban lampu yang diberikan dalam proses pembebanan, maka semakin menurun putaran dari kincir air yang dihasilkan dan hasil penelitian yang telah dilakukan menunjukkan semakin turun posisi kincir air maka putaran kincir air semakin besar. Semakin besar debit air yang mengenai sudu air, semakin kencang putaran kincir [15]. Penelitian yang telah dilakukan terlihat bahwa posisi poros kincir $21 \mathrm{~cm}$ yang berada di atas bibir saluran pada pembebanan lampu 20 Watt menghasilkan putaran kincir 40,3 rpm, sedangkan pada pembenanan 40 Watt menghasilkan putaran kincir 38,3 rpm. Karakteristik Variasi Beban Lampu 
Baktiyar Mei Hermawan dkk /Jurnal Rekayasa Mesin

p-ISSN: 1411-6863, e-ISSN: 2540-7678

Vol.16|No.3|475-485|Desember|2021

terhadap Daya Listrik dapat dilihat pada Gambar 13.
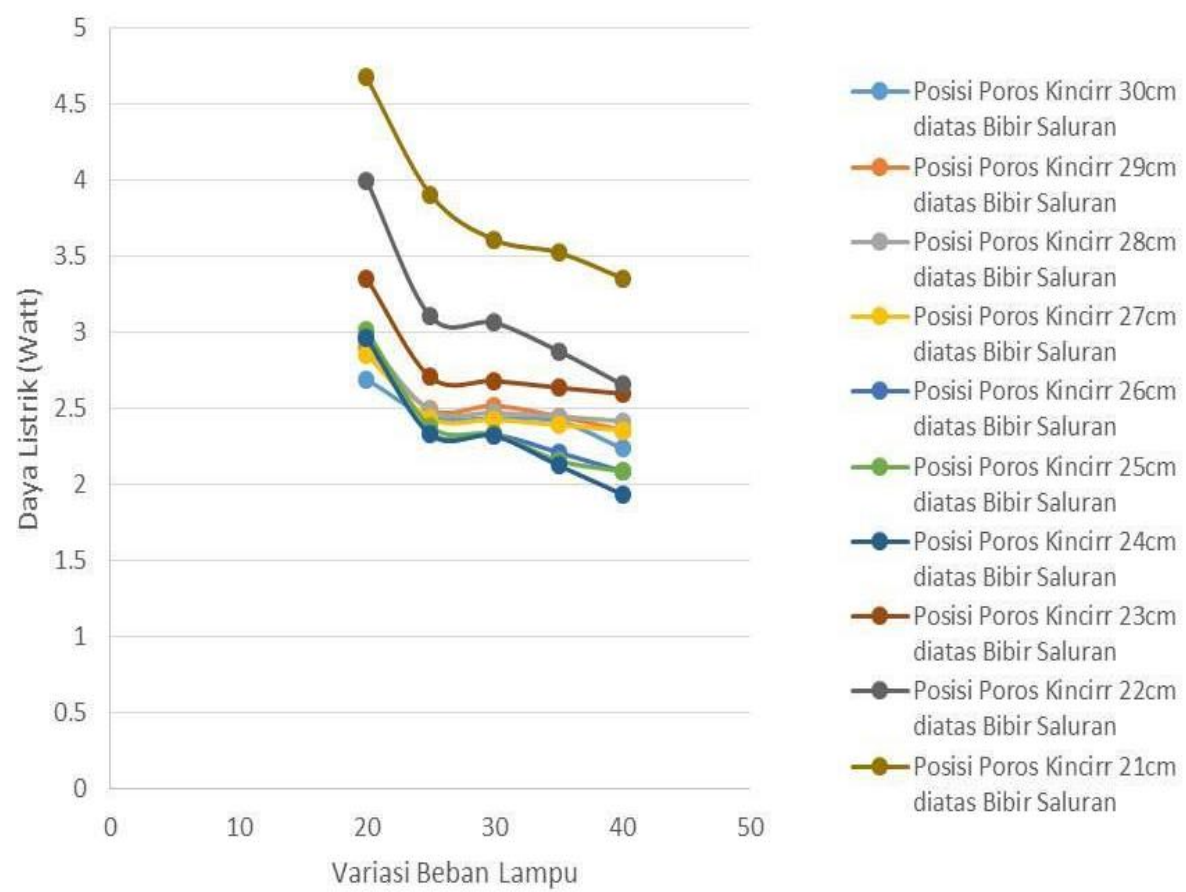

Gambar 13. Karakteristik Variasi Beban Lampu terhadap Daya Listrik

Gambar diatas terlihat bahwa semakin tinggi beban yang terpasang, maka semakin rendah pula daya listrik yang dihasilkan dan semakin turun posisi kincir maka daya lisrik semakin besar. Dapat terlihat bahwa posisi poros kincir 21 cm di atas bibir saluran pada beban lampu 20 Watt menghasilkan daya listrik 4,68 Watt. Sedangkan pada beban 40 Watt menghasilkan daya listrik 3,36 Watt. Karakteristik Variasi Beban Lampu terhadap Efisiensi Sistem dapat dilihat pada Gambar 14 .

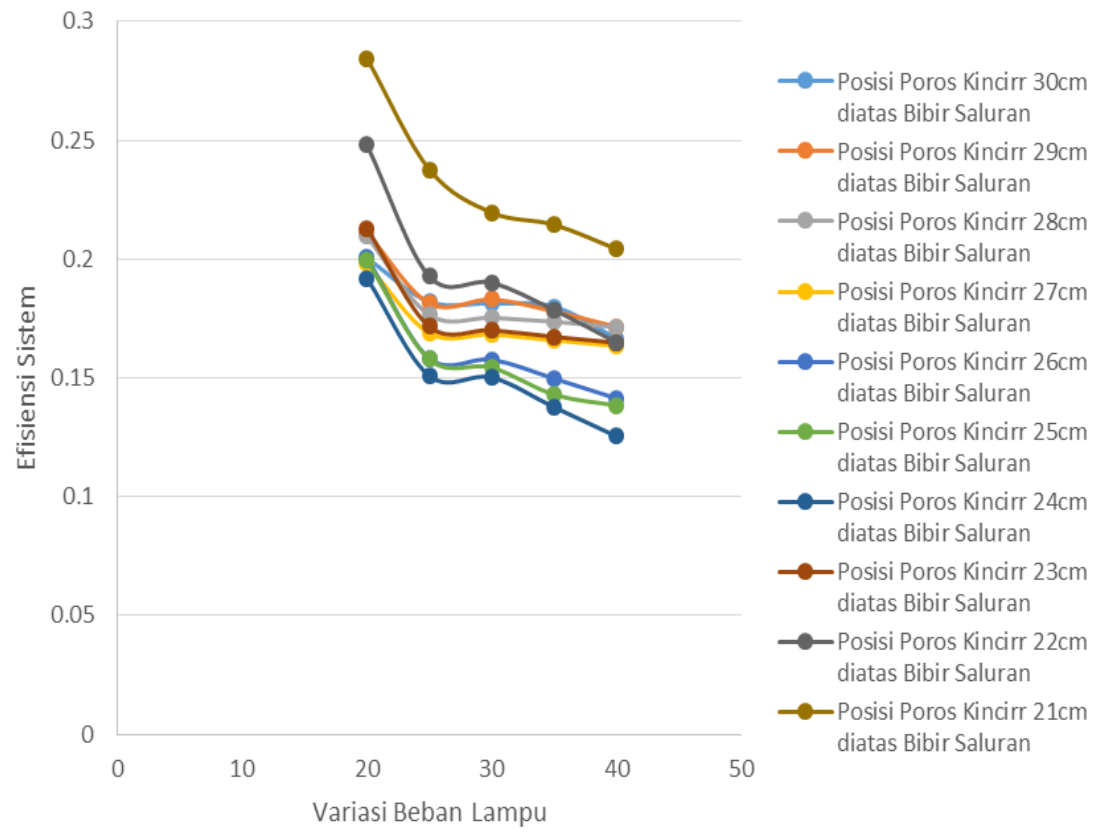

Gambar 14. Karakteristik Variasi Beban Lampu terhadap Efisiensi Sistem

Gambar 14 terlihat bahwa semakin tinggi beban yang terpasang, maka semakin rendah pula efisiensi sistem yang 
Baktiyar Mei Hermawan dkk /Jurnal Rekayasa Mesin p-ISSN: 1411-6863, e-ISSN: 2540-7678 Vol.16|No.3|475-485|Desember|2021

dihasilkan dan semakin turun posisi kincir maka efisiensi sistem semakin besar. Dapat terlihat bahwa posisi poros kincir $21 \mathrm{~cm}$ di atas bibir saluran pada beban lampu 20 Watt menghasilkan efisiensi sistem $0,284 \%$. Sedangkan pada beban 40 Watt menghasilkan efisiensi sistem $0,204 \%$.

Posisi kincir mempengaruhi daya hidrolik, semakin tinggi sudu kicir air yang terkena air semakin besar pula daya hidrolik yang dihasilkan. Meskipun efisiensi sistem berbanding terbalik dengan daya hidrolik namun bertambah besarnya daya hidrolik diiringi dengan bertambah besar pulanya daya generator. Maka efisiensi sistem tertinggi diperoleh pada posisi ketinggian poros kincir terendah yaitu pada $21 \mathrm{~cm}$ dari bibir saluran pada beban lampu 20 Watt menghasilkan efisiensi sistem 0,284\%. Sedangkan pada beban 40 Watt menghasilkan efisiensi sistem 0,204\%.

\section{Kesimpulan}

Pengujian yang telah dilakukan dalam penelitian ini dapat ditarik suatu kesimpulan yaitu putaran kincir tertinggi pada ketinggian poros kincir $21 \mathrm{~cm}$ diatas bibir saluran adalah 40,3 rpm dengan beban lampu 20 Watt, sedangkan putaran kincir terendah pada ketinggian poros $29 \mathrm{~cm}$ diatas bibir saluran adalah $35,9 \mathrm{rpm}$ dengan beban lampu 40 Watt. Daya listrik tertinggi pada ketinggian poros kincir $21 \mathrm{~cm}$ diatas bibir saluran adalah 4,68 Watt dengan beban lampu 20 Watt. Sedangkan daya listrik terendah pada ketinggian poros $24 \mathrm{~cm}$ diatas bibir saluran adalah 1,938 Watt dengan beban lampu 40 Watt. Efisiensi sistem tertinggi pada ketinggian poros kincir $21 \mathrm{~cm}$ diatas bibir saluran adalah 0,284\% dengan beban lampu 20 Watt. Sedangkan efisiensi sistem terendah pada ketinggian poros 24 diatas bibir saluran $\mathrm{cm}$ adalah $0,125 \%$ dengan beban lampu 40 Watt. Karakteristik kinerja kincir air dihasilkan efisiensi sistem tertinggi sebesar 0,284\% pada putaran kincir 40,3 rpm yang menghasilkan daya listrik sebesar 4,68 Watt pada posisi ketinggian poros 21 $\mathrm{cm}$ diatas bibir saluran dan pada beban 20 Watt. Sedangkan efisiensi terendah sebesar 0,125\% pada putaran 35,9 rpm yang menghasilkan daya listrik sebesar 1,938 Watt

\section{Ucapan Terima Kasih}

Terima Kasih Kepada P3M Politenik Negeri Semarang yang telah mendanai penelitian ini dalam Penelitian Terapan Unggulan Program Studi Politeknik Negeri Semarang Tahun Anggaran 2021 .

\section{Daftar Pustaka}

[1] Khotimah, K. 2018. Membangun Kekuatan Pertahanan Melalui Pengelolaan Energi Terbarukan Berbasis Kearifan Lokal Masyarakat. Jurnal Pertahanan \& Bela Negara 2018, Volume 8 Nomer 3.

[2] Anonim. Kebijakan Pengembangan Tenaga Air. http://ebtke.esdm.go.id/post/2014/07/02/628/ kebijakan. pengembangan.\%20tenaga.air, 2014 (diakses pada tanggal 21 Maret 2021)

[3] Anonim. Energi Air Terangi Jawa Tengah. http:// ebtke.esdm.go.id/post/2015.terangi.jawa.tengah, 2015 (diakses pada tanggal 22 Maret 2021).

[4] Suratmaja, S, dkk. 2020. Optimalisasi Kinerja Kincir Air Dengan Menggunakan Material Almunium Tipe Undershot. Jurnal JMMME, Volume 1, Nomor 2, Oktober 2020.

[5] Farid, Akhmad. 2018. Uji Kinerja Turbin Mikro Hidro Dengan Variasi Jumlah Sudu Berbentuk Setengah Lingkaran. Jurnal PROTON, Vol.10 No.2/Hal 7-11.

[6] Silaen, Antonius F A. 2015. Pengaruh Beban Terhadap Putaran Turbin Helikal Untuk Pembangkit Tenaga Listrik. Majalah Teknis Simes Vol 9 No.2 Juli 2015

[7] Wong, Keng Lie Irwan, dkk. 2019. Analisis Unjuk Kerja Kincir Air Undershot Di Desa Saluputti. Prosiding 
Baktiyar Mei Hermawan dkk /Jurnal Rekayasa Mesin

p-ISSN: 1411-6863, e-ISSN: 2540-7678

Vol.16|No.3|475-485|Desember|2021

Seminar Nasional Penelitian\& Pengabdian Kepada Masyarakat 2019 (pp.177-180)

[8] S, Gatot., Kaji Eksperimental Kinerja Turbin Air Hasil Modifikasi Pompa Sentrifugal Untuk Pembangkit Listrik Tenaga Mikrohidro. Prosiding Seminar Nasional Sains dan Teknologi 3 2012. Vol 1 nomor 1 (2012).

[9] S, Gatot., Bono, Yusuf DH. 2007. Optimasi Turbin Crossflow Terhadap Variasi Sudut Sudu pengarah untuk Pembangkit Listrik Tenaga Mikrohidro. Jurnal Eksergi. Vol 3 nomor 1 hal 22-28. ISSN 0216- 86

[10] Sahid, Bono, Suanrwo. 2006. Pengaruh Nosel Berpenampang Segi Empat Terhadap Unjuk Kerja Turbin Pelton Mikro Untuk Sistem Pembangkit Listrik Tenaga Mikrohidro. Forum Tekni, vol 30 no. 1, Januari 2006 hal 48 55. ISSN 0216- 7565

[11] Wibawa, U., Santoso, H., \& Dharmayana, I. G. A. (2014). Perancangan Kincir Air Pembangkit Listrik Tenaga Mikrohidro (PLTMH) Desa Bendosari Kecamatan Pujon Kabupaten Malang. Jurnal Elektro Unika Atma Jaya, $7(1), 45-58$.

[12] Ristianto, P, Sunardi. 2019. Generator ganda pada Pembangkit Listrik Mikrohidro dengan Turbin Tunggal. AVITEC, Vol. 1, No. 1, Agustus 2019

[13] Rahman, A, Kimin. 2018. Pengaruh Debit Air Terhadap Kinerja Kincir Air. Jurnal DINAMIS Vol 2. No. 12 Desember 2018 hal 76-79

[14] Suryanta, dkk. 2018 Studi Potensi dan Pemanfaatan Aliran Sungai Untuk PLTMH Menggunakan Kincir Air Sudu Bersirip. Jurnal Ilmiah Teknologi FST Undana Vol.12 No.2 hal 32-39

[15] Novrianto, dkk. 2019. Efisiensi Kincir Air Tipe Breastshot Pada Prototipe Pembangkit Listrik Tenaga Mikrohidro. Jurnal Elektrikal, Volume 6 Nomor 1, Juni 2019, 26-34. 